\title{
PENAMBAHAN SARI KUNYIT (Curcuma domestic Val) TERHADAP PERTAMBAHAN BERAT BADAN DAN KONSUMSI PAKAN AYAM PETELUR JANTAN
}

\author{
Andri Dwi Efendi ${ }^{1)}$, Nita Opi Ari Kustanti ${ }^{2)}$, Adi Andaka ${ }^{2)}$ \\ ${ }^{1)}$ Mahasiswa Program Studi Ilmu Ternak Fakultas Peternakan \\ ${ }^{2)}$ Dosen Program Studi Ilmu Ternak Fakultas Peternakan \\ Universitas Islam Balitar \\ J1. Majapahit No. 04 Kota Blitar
}

\begin{abstract}
It has been done a research about Curcuma Domestic Val to egg-type cockerels of hen. This research is knowing about of effect curcuma domestic val to increas weight a hen. Its used a egg-type cockerels strain Isa Brown from PT. Charoen Pokphand Indonesia more than 60 hens that old is 30 days until 58 days is ready, and curcuma domestic val that fresh juice. After 30 days old, its been done to 12 team of boxes. Every box has been 5 hens, then doing it until 1-12 agains, to 12 team of boxes assigned into 4 treatments with 3 replication. This research used experiment that completely randomized design with 4 kinds of method. According this research, can be summary that to added Curcuma Domestica Val with water can't real effect to in crease weight ( $\mathrm{P}>0.05)$, with higher to P0,P1,P2,P3. That mean is 89,6 , $895,873,3,864,3$, its must to do research more than extra about to added Curcuma Domestic Val with volume more than $50 \mathrm{ml} / 1000 \mathrm{ml}$ water to added weight of egg-type cockerels, so its can to know size how much ml Curcuma Domestic Val that can be responses.
\end{abstract}

Keywords : Egg-type cockerels:, Body Weight, Curcuma Domestic Val

\section{PENDAHULUAN}

Usaha untuk meningkatkan produktivitas ayam harus terus digalakkan seiring dengan meningkatnya kebutuhan masyarakat akan produk komoditas ayam baik berupa telur maupun daging. Kontribusi daging ayam terhadap produksi daging nasional semakin meningkat dari 20 $\%$ pada tahun 70 -an menjadi 65 persen (1.403,6 ribu ton) pada tahun 2008. Perubahan struktur tersebut disebabkan produksi daging ayam yang semakin meningkat sejalan dengan peningkatan industri perunggasan nasional. Sementara itu, industri sapi potong yang masih mengandalkan industri peternakan rakyat dengan dukungan pihak industri belum mampu mengimbangi permintaan daging sapi domestik, kontribusinya menurun tahun 70-an menjadi $16 \%$ dari $54 \%$ pada tahun 2008. Fenomena yang terjadi adalah laju peningkatan daging ayam lebih tinggi dibandingkan laju peningkatan produksi daging sapi. Artinya dengan teknologi yang semakin meningkat pada industri perunggasan menyebabkan terjadi transformasi produksi dari dominasi sapi ke dominasi ayam (Ditjennak 2010). Komoditas masyarakat Indonesia secara umum mengenal 2 jenis ayam, yaitu ayam ras dan ayam buras, ayam buras adalah ayam bukan ras yaitu ayam kampung, sedangkan ayam ras adalah ayam yang di impor dari luar negeri bersifat unggul karena telah mengalami perbaikan secara genetis. Jenis ayam ras ada 2, yaitu ayam broiler dan ayam petelur jantan (Supriyatna dkk, 2005).

Dengan perkembangan waktu, pertambahan jumlah penduduk, peningkatan pendapatan dan kesadaran masyarakat akan arti pentingnya gizi bagi kesehatan tubuh, maka 
permintaan masyarakat akan kebutuhan pangan sumber protein hewani semakin meningkat. Salah satu pangan sumber protein hewani yang digemari oleh masyarakat adalah daging ayam. Daging ayam yang dikonsumsi biasanya berasal dari daging broiler dan daging ayam kampung. Namun, ketersedian akan ayam kampung masih terbatas dan harganya relatif mahal. Oleh sebab itu, ada alternatif lain yang digunakan untuk menggantikan daging ayam kampung yaitu daging ayam petelur jantan.

Telah banyak rumah makan yang menjadikan ayam petelur jantan sebagai salah satu menu utamanya. Cita rasa ayam jantan yang hampir mirip dengan ayam kampung telah membantu mencukupi permintaan akan daging ayam kampung yang kian hari kian sulit di dapat. Ayam petelur jantan saat ini dijadikan produk substitusi untuk ayam kampung karena tekstur dan rasa yang menyerupai ayam kampung. Ayam ini memiliki keunggulan tahan terhadap penyakit, secara relatif harga jual yang lebih tinggi dari ayam broiler, bobot panen dapat diatur dengan pengaturan protein pakan untuk menyesuaikan dengan keadaan pasar dan umumnya dipasok ke rumah makan atau restoran. Berbagai upaya telah banyak dilaksanakan oleh para peternak untuk memacu pertumbuhan, meningkatkan efisiensi penggunaan pakan dan meningkatkan status kesehatan ayam, salah satu upaya tersebut adalah dengan meningkatkan nafsu makan. Kunyit mengandung senyawa kurkumin yang dapat menambah nafsu makan. Kunyit dapat diberikan pada ayam dalam berbagai cara yaitu bentuk tepung kunyit, ekatraksi kunyit dan sari kunyit. Pemberian dalam bentuk sari kunyit lebih mudah diterapkan oleh para peternak dan kandungan kurkumin dalam kunyit masih aktif. Kandungan utama rimpang kunyit adalah minyak atsiri, kurkumin, resin, oleoresin, desmetoksi kurkumin dan bisdemetoksikurkumin, senyawa lainnya pati , gom, lemak, protein, kalsium, dammar, kamfer, resin, fosfor dan besi. Kandungan kimia minyak atsiri kunyit terdiri atas ar-tumeron, alfa, beta tumeron, alfa atlanton, beta kariofilen, linalol, 1,8 sineol, zin-geberen, dd felandren dan d-sabinen (Anonim, 2006 disitasi oleh Ahmad k, 2012).

Hermanu (2008) melaporkan bahwa sari kunyit meningkatkan nafsu makan pada tikus albino. Berdasarkan dengan uraian diatas maka peneliti tertarik mengenai " Penambahan sari kunyit (Curcuma domestik val) terhadap pertumbuhan ayam petelur jantan" Hasil penelitian ini diharapkan dapat memberikan informasi kepada pembaca tentang potensi penambahan sari kunyit pada air minum terhadap konsumsi pakan dan pertumbuhan bobot ayam petelur jantan.

\section{MATERI DAN METODE PENELITIAN}

Materi yang digunakan pada penelitian ini adalah ayam petelur jantan strain Isa Brown dari PT. Charoen Pokphand Indonesia sebanyak 60 ekor yang berumur 30 hari hingga panen pada umur 58 hari, sari kunyit (Curcuma domestica Val). Pakan yang digunakan adalah BR 1 dari PT. Cargill Indonesia dengan komposisi disajikan pada Tabel.

Tabel 1. Komposisi pakan BR 1

\begin{tabular}{|l|c|}
\hline \multicolumn{1}{|c|}{ Komponen } & Kadar \\
\hline Kadar air & Maks $12,0 \%$ \\
\hline Protein Kasar & Min $20,5 \%$ \\
\hline Lemak & Maks $7,4 \%$ \\
\hline Serat & Maks $6,0 \%$ \\
\hline Abu & Maks $8,0 \%$ \\
\hline Monensin & $90-110 \mathrm{ppm}$ \\
\hline Enramycin $\mathrm{n}$ & $5-10 \mathrm{ppm}$ \\
\hline
\end{tabular}

Sumber : PT. Cargill Indonesia 
Alasan mengapa perlakuan diberikan pada ayam petelur jatan umur 30 hari adalah untuk menghindari hal-hal yang dapat mempengaruhi sifat-sifat organoleptik pada daging ayam maupun kerusakan organ akibat pemberian kunyit yang tinggi ( Asmarasari, 2008). Peralatan yang digunakan antara lain adalah; Kandang liter untuk pemeliharaan berukuran $3 \mathrm{~m} \times 2,25 \mathrm{~m}$ yang terbagi menjadi 12 petak dan ukuran tiap 1 petak adalah $75 \mathrm{~cm} \times 75 \mathrm{~cm}$, tiap petak berisi 5 ekor ayam. Savitri (2010) mengatakan, bahwa pada kepadatan 10 ekor/m2 untuk ayam jantan tipe medium menunjukan pengaruh yang terbaik. Tempat makan dan minum, setiap petaknya diberi 1 tempat makan dan 1 tempat minum.Sekat pembatas, tirai luar dan tirai dalam.Lampu 100 Watt buat penerangan.Timbangan digital untuk menimbang ayam, sisa pakan, sisa air dan timbangan duduk buat menimbang kunyit.Kamera digital buat dokumentasi.Peralatan untuk membuat sari kunyit antara lain:Pisau kupas untuk mengupas kunyit. Blender untuk untuk melembutkan kunyit agar memudahkan dalam mengambil sari kunyit. Sarigan, gelas ukur dan air.

\section{Variabel pengamatan}

Parameter yang diukur dalam penelitian ini adalah :

1) Konsumsi pakan.

Konsumsi pakan diukur setiap hari dengan cara ransum yang diberikan (gram) dikurang ransum sisa (gram) kemudian dibagi jumlah ayam (ekor).

Ransum yang diberikan- Ransum sisa

2) Konsumsi air

Konsumsi pakan $(\mathrm{g} / \mathrm{ekor} / \mathrm{hari})=$

Dihitung menggunakan rumus:

$$
\text { Jumlah Ayam }
$$

Air minum yang diberikan

Konsumsi air (L/ekor/hari) $=$

3) Pertambahan Berat Badan

$$
\text { Jumlah ayam }
$$

Pertambahan berat badan diukur setiap minggu dengan cara berat badanakhir minggu (berat akhir) dikurang berat badan minggu sebelumnya (berat awal).

$\mathrm{PBB}(\mathrm{g}) \quad=\mathrm{BB}_{\mathrm{t}}(\mathrm{g})-\mathrm{BB}_{\mathrm{t}-1}(\mathrm{~g})$

Keterangan :

PBB = Pertambahan berat badan

$\mathrm{BB}_{\mathrm{t}}=$ Berat badan akhir minggu (berat akhir)

$\mathrm{BB}_{\mathrm{t}-1}=$ Berat badan minggu sebelumnya (berat awal)

$\mathrm{t} \quad=$ Waktu pengukuran ( satu minggu )

\section{Analisis data}

Rancangan yang akan digunakan dalam penelitian ini adalah Rancangan Acak Lengkap dengan variabel yang diukur yaitu konsumsi pakan, pertambahan berat badan dan konversi pakan.

Model matematis rancangan ini adalah:

$\mathrm{Y}_{\mathrm{ij}}=\mu+\mathrm{p}_{\mathrm{i}}+\sum_{\mathrm{ij}}$

Dimana:

$\mathrm{Y}_{\mathrm{ij}} \quad$ : Nilai pengamatan pada perlakuan ke-i dan ulangan ke-j

$\mu \quad$ : Nilai tangan ke-i

$\mathrm{p}_{\mathrm{i}} \quad$ : Pengaruh perlakuan ke-i

$\sum_{\mathrm{i}} \quad$ : Galat perlakuan ke-i dan ulangan ke-j 
Data yang diperoleh akan di analisis dengan menggunakan. Data yang diperolah akan dianalisis dengan Sidik Ragam (ANOVA) dan jika hasil berbeda nyata maka akan diuji dengan Uji Jarak Berganda Duncan (DMRT).

\section{HASIL DAN PEMBAHASAN}

Hasil pengamatan penambahan jus kunyit terhadap komsumsi pakan ayam petelur jantan pengaruh nyata, bisa dilihat tabel sebagai berikut:

Tabel 2. Data konsumsi ransum pada ayam petelur jantan selama penelitian

\begin{tabular}{|c|c|c|c|c|}
\hline Ulangan & P0 & $\mathrm{P} 1$ & $\mathrm{P} 2$ & P3 \\
\hline 1 & 890 & 965 & 840 & 845 \\
\hline 2 & 880 & 855 & 845 & 818 \\
\hline 3 & 920 & 865 & 935 & 930 \\
\hline Rata-rata & 897 & 895 & 873 & 864 \\
\hline
\end{tabular}

Sumber : Data primer yang di olah (2015)

Hasil analisis sidik ragam menunjukkan bahwa level penambahan sari kunyit pada 1000 $\mathrm{ml}$ air minum berpengaruh nyata $(\mathrm{P}<0,05)$ terhadap komsumsi ransum ayam petelur jantan pada perlakuanp P1 dan P3 dengan rataan 53,8 dan 59,4 (gr/ekor/hari) dibandingkan dengan perlakuan control P0 dengan rataan 65,8 (gr/ekor/hari). Pratikno H (2010) menunjukkan bahwa penambahan ekstrak kunyit sampai $400 \mathrm{mg} /$ hari dalam ke ayam pedaging secara oral dalam bentuk kapsul ternyata menurunkan konsumsi pakan dan konversi pakan, tetapi menaikan pertumbuhan bobot badan, sedangkan Achmad, dkk (2012), Pemberian tepung kunyit sebanyak $0,6 \%$ dalam ransum ayam pedaging dapat meningkatkan bobot badan serta daya tahan tubuh ayam pedaging (Agustiana, 1996 disitasi oleh Khumaini A, 2012) .

\section{Pertambahan Bobot Badan}

Hasil pengamatan penambahan jus kunyit terhadap bobot badan rata-rata pertambahan berat badan ayam petelur jantan berdasarkan hasil penelitian tertinggi adalah $897 \mathrm{gr}$ (P0) dan terendah 864gr (T0). Hasil analisis variansi dan rerata menunjukkan bahwa tidak terdapat perbedaan $(\mathrm{P}>0.05)$ pertambahan berat ayam ayam petelur jantan dengan penambahan sari kunyit pada air minum. Data pertambahan berat badan ayam petelur jantan yang diberi sari kunyit dalam air minum tertera pada tabel berikut :

Tabel 3. Data pertambahan bobot badan ayam petelur jantan selama penelitian (gr/ekor/hari).

\begin{tabular}{|c|c|c|c|c|}
\hline Ulangan & P0 & P1 & P2 & P3 \\
\hline 1 & 66 & 54,8 & 64,4 & 61 \\
\hline 2 & 65 & 49,6 & 66,2 & 58 \\
\hline 3 & 66,4 & 57,2 & 66,8 & 59,2 \\
\hline Rata-rata & 65,8 & 53,8 & 65,8 & 59,4 \\
\hline
\end{tabular}

Sumber : Data primer yang di olah (2015).

Penelitian Khumaini A (2012) melaporkan bahwa menambahan sari kunyit sebanyak 10-30 gr/hari pada air minum tidak ada perbedaan bobot badan pada ayam broiler $(\mathrm{P}>0.05)$. 


\section{Pengaruh Konsumsi Pakan Terhadap Pertumbuhan Bobot Badan}

Tabel 4. Pengaruh konsumsi pakan terhadap pertumbuhan bobot badan.

\begin{tabular}{|c|c|c|}
\hline Perlakuan & Konsumsi Pakan & Pertumbuhan bobot badan \\
\hline P0 & 65,8 & 896,6 \\
\hline P1 & 56,2 & 895 \\
\hline P2 & 65,8 & 873,3 \\
\hline P3 & 59,4 & 864,3 \\
\hline
\end{tabular}

Sumber : Data primer yang di olah (2015).

Dari tabel 4 dapat disimpulkan kalau perlakuan P3 komsumsinya pakannya lebih sedikit ketimbang $\mathrm{P}$ kontrol, sedangkan pertumbuhan bobot badannya lebih rendah dari padaP kontrol, dengan urutan komsumsi pakan terendah ke tertinggi P2, P3,P1, P0.

Tabel 5. Pemberian pakan dan berat badan ayam jantan.

\begin{tabular}{|c|c|c|}
\hline $\begin{array}{c}\text { Umur } \\
\text { (Minggu) }\end{array}$ & Pakan(gram/hari/ekor) & $\begin{array}{c}\text { Beratbadan } \\
\text { (gram) }\end{array}$ \\
\hline 1 & 11 & 85 \\
\hline 2 & 18 & 170 \\
\hline 3 & 25 & 275 \\
\hline 4 & 33 & 390 \\
\hline 5 & 39 & 520 \\
\hline 6 & 44 & 660 \\
\hline 7 & 48 & 785 \\
\hline 8 & 52 & 910 \\
\hline 9 & 56 & 1035 \\
\hline
\end{tabular}

Sumber: ISA Brown(2007)

Dari data di atas dapat dilihat kalau konsumsi pakan P1 lebih banyak dari pada yang di leteratur dan bertumbuhan bobot badanya juga lebih rendah, sedangkan P2 mendekati sama komsumsi pakannya tapi pertumbuhan bobot badanmya lebih rendah. Adi (2009) disitasi oleh Diora dkk, (2013) mengatakan minyak atsiri yang dikandung kunyit dapat mempercepat pengosongan isi lambung. Hal ini menimbulkan keterikatan antara fungsi dari kunyit terhadap proses konsumsi dan konversi pakan ayam berpengaruh dalam pembentukan daging sertamenghasilkan pertambahan berat badan ayam yang optimal (Bintang dan Natamijaya, 2005 disitasi oleh Diora dkk, 2013).

\section{KESIMPULAN DAN SARAN Kesimpulan}

Berdasarkan penelitian dapat disimpulkan bahwa penambahan sari kunyit pada air minum tidak berpengaruh nyata terhadap pertumbuhan bobot badan, dengan urutan tertinggi ke terendah PO,P1,P2,P3 rataan 896,6, 895, 873,3, 864,3.

Saran

Perlu dilakukan penelitian lebih lanjut mengenai pengaruh penambahan sari kunyit dengan volume di atas $50 \mathrm{ml}$ pada $1000 \mathrm{ml}$ air minum terhadap pertumbuhan bobot badan ayam layer jantan dan perlu dilakukan penelitian kembali mengenai pengaruh sari kunyit terhadap pertumbuhan bobot badan ayam petelur jantan sehingga mendapatkan penambahan sari kunyit dengan takaran yang tepat. 


\section{DAFTAR PUSTAKA}

Alfin H. 2009. Evaluasi Kecukupan Nutrien Pada Ransum Ayam Broiler Di Peternakan Cv Perdana Putra Chicken Bogor. Universitas Diponegoro. Semarang.

Ahmad, A.W. 2011. Strategi Pengembangan Usaha Ayam Petelur Jantan Pada Ud utri Poultry Shop Di Desa Gadingsari Kecamatan Sanden Kabupaten Bantul. Institut Pertanian.Bogor.

Alamsyah, R. 2005. Pengolahan Pakan Ayam dan Ikan Secara Modern. Penebar Swadaya. Jakarta.

Asmarasari dan E. Suprijatna. 2008. Pengaruh Penggunaan Kunyit Dalam Ransum Terhadap Performans Ayam Pedaging.Fakultas Peternakan Universitas Diponegoro. Bogor.

Asriyanti. 2013. Mempelajari Pembuatan Bumbu Inti Kunyit (Curcuma Domestica Val) Bubuk.Jurusan Teknologi Pertanian Fakultas Pertanian Universitas Hasanuddin. Makasar.

Diora K.N, Sunaryo, Utomo, Mirni L dan Mahasiswa. 2013. Departemen Peternakan Veteriner, Departemen Kedokteran Dasar Veteriner, Departemen Peternakan Veteriner Fakultas Kedokteran Hewan. Universitas Airlangga.

Direktorat pembinaan SMK. 2008. Pemeliharaan Ayam Petelur Jantan. Agribisnis Ternak Unggas.

Imelda O, Utami H, Tri A. 2007. Analis Usaha Peternakan Petelur Jantan Pada Berbagai Skala Usaha Di Peternakan Plasma Poultry Shop (Ps) Sukahati, Kabupaten Tasikmalaya. Fakultas Teknologi Pertanian dan Peternakan. Universitas Semarang.

Kartasudjana dan Edjeng S. 2006. Manajemen Ternak Unggas. Penebar Swadaya. Jakarta.

Khumaini A, Roisu E, Mudawaroch dan Hanung D. 2012. Pengaruh Penambahan Sari Kunyit (Curcuma Domestica Val) Dalam Air Minum Terhadap Konsumsi Pakan Dan Konsumsi Air Minum.universitas muhamadiyah.purworejo.

Pratikno, H. 2010. Pengaruh Ekstrak Kunyit (Curcuma domestica Vahl) Terhadap Bobot Badan Ayam Broiler (Gallus sp). Fakultas Peternakan Universitas Diponegoro. Semarang.

Savitri, F. 2010. Pengaruh Tingkat Kepadatan Kandang terhadap Bobot Hidup, Bobot Karkas, dan Bobot Lemak Abdominal Ayam Jantan Tipe Medium. Skripsi. Fakultas Pertanian, Universitas Lampung. Lampung.

Suprijatna E, Umiyati dan Ruhyat K. 2005. Ilmu Dasar Ternak Unggas. Penebar Swadaya. Jakarta.

Wafiatiningsih dan Bariroh. 2010. Pengaruh Penggunaan Tepung Kencur Sebagai Feed Suplemen Terhadap Karkas Ayam Petelur Jantan. Balai Pengkajian Teknologi Pertanian. Kalimantan Timur.

Yuni S. 2013. Warta Penelitian Pengembangan Tanaman Industri, Volume 19 Nomor 2 
Yupi. 2010. Analisis Ayam Petelur. Universitas Islam Negeri Syarif Hidsyatullah Jakarta.

Zulfikar. 2013. Manajemen Pemeliharaan Ayam Petelur Ras. Pasca Sarjana Kesehatan Masyarakat Veteriner (Kesmavet). Unsyiah. 